\title{
MÚSICA Y PINTURA EN LA POESÍA DE ÁNGEL GONZÁLEZ
}

José EnRiQue Martínez

Universidad de León

Durante siglos, la relación entre las artes correspondió a la reflexión filosófica, antes de ser asumida por la estética y en la actualidad por la literatura comparada. Se trataba y se trata de hallar la raíz común o diferenciada de las distintas formas artísticas. Hoy no preocupa tanto como antaño la jerarquía entre las artes, pero es la lengua (la literatura) la que ejerce la función mediadora entre las mismas: «La literatura no es totalizadora ni puede arrogarse el status de un super-arte. Pero ciertamente es a través de la lengua como se produce la reflexión entre todas las artes» (Pantini, 2002: 223), entre la música, la pintura, la escultura, la arquitectura, la danza, el cine y la literatura. Esta ha mantenido fecundas relaciones tradicionalmente con la música y la pintura, y modernamente con el cine. Los análisis concretos de las relaciones interartísticas dibujan diferentes caminos que, en el caso de la literatura, suponen el aprovechamiento de textos literarios por otras artes o el aprovisionamiento de temas y técnicas artísticas por parte de la poesía. En este juego interartístico caben todo tipo de interacciones: colaboraciones entre músicos y poetas o entre poetas y pintores, grafismos emparentados con la pintura o con la música, poemas inspirados en un lienzo, una escultura, una obra arquitectónica o una pieza musical, temas, mitos y tópicos que cruzan transversalmente las distintas manifestaciones artísticas, etc. Las relaciones interartísticas analizadas en este trabajo tienen, sin embargo, un único sentido direccional: la presencia de otras artes - música y pintura en concreto- en la poesía de Ángel González. 
Con frecuencia la crítica aplica el término «musicalidad» a una determinada composición poética. No es más que una metáfora alusiva a sensaciones equiparables a las que provienen de la música o que connotan creencias o tradiciones diversas, pitagóricas («música de las esferas»), místicas ("música callada») o de otro tipo. Cuestión distinta es que el poema acoja referencias musicales (a sinfonías, conciertos, óperas, melodías, canciones, compositores, cantantes...) o que el tema del poema sea de orden musical, que utilice términos o conceptos musicales de modo metafórico o simbólico (contrapunto, acordes, violines celestiales), que aproveche intertextualmente letras de canciones, que el poema mismo haya sido concebido para ser musicalizado o que tome como modelo letras ya conocidas (de tango, blues, bolero, etc.). Cabe que el poeta intente imitar determinados ritmos musicales, pero sus poemas nunca se confundirán con una composición musical. El poeta Carlos Pardo señala que para evitar el ritmo tradicional del endecasílabo «intentaba imitar las polirritmias de algunos discos de jazz» (Pardo, 2013: 80). La música, por lo tanto, puede inspirar la búsqueda de un ritmo poético nuevo o diferente, que traduzca en palabras, por ejemplo, la expresión musical del dolor, como muestra un título significativo, Blues castellano (1982) de Antonio Gamoneda (1997); pero se trata, en su resultado, de ritmo poético, por más que remita originariamente al ritmo (y la letra) de los cantos fundacionales del jazz, el blues y el spiritual. Música y poesía son artes cuya complicidad a lo largo de los siglos, desde los comienzos mismos de la poesía, no es preciso traer a cuento; se trata, en estas líneas iniciales, de desmontar la confusión tradicional de considerar elementos musicales el ritmo y la sonoridad poéticas, en línea con dos trabajos recientes, de Jorge Urrutia (2013) y de Carlos Pardo (2013) respectivamente.

Urrutia aboga por prescindir del concepto musical alusivo a la sonoridad poética, algo que atribuye en sus orígenes a los románticos, si bien ellos entendían la música, en sentido amplio, como metáfora o como símbolo de la armonía universal. Baudelaire acuñaría literariamente la correspondencia entre los distintos tipos de sensaciones. Era el momento del auge de la sugerencia como efecto artístico. Cuando Verlaine pedía en su «Art poétique» la música ante todo, «lo que hacía era defender el arte de la sugerencia, sin intermediarios racionales, discursivos y afectivos, entendiendo que el arte de la sugerencia más evidente era la música, y no reclamaba transposición alguna de los elementos musicales al poema» 
(Urrutia, 2013: 129). Añade Urrutia que el compositor trabaja con sonidos, mientras que el poeta no puede prescindir de los contenidos, por lo que el ritmo poético no lo crean solo los elementos sonoros del lenguaje, sino también los espaciales y conceptuales. La música aplicada a la poesía no es, pues, más que una metáfora alusiva al ritmo poético en un sentido superador de la superficie sonora del poema, pues atañe fundamentalmente al «acompasamiento de los conceptos», que es «lo que permite la existencia del verso libre y la prosa poética en sus distintas manifestaciones» (ibíd.: 130). También el poeta Carlos Pardo alude al romanticismo como motivador de un «ámbito compartido por todas las artes», con la música en la cima por su carácter abstracto o no referencial. La poesía intentará, por ello, aproximarse a la música por medio de la zona más imprecisa del lenguaje, la sugerencia (Pardo, 2013: 84). No interesa aquí la panoplia de ideas que despliega Pardo en torno a las relaciones entre las dos artes, música y poesía, sino la que afirma que la fecundidad de la relación se centra en «la manera que han tenido los poetas [...] de apropiarse de metáforas musicales como incentivo de su trabajo» (ibíd.: 80).

En la poesía de Ángel González no son escasas las metáforas musicales, ni son escasos los poemas de tema o referencia musical, los dos ámbitos que aborda este trabajo. Pertenece el poeta asturiano a una generación que, «formada en la música popular en unos tiempos en los que la radio era un medio de subversión de la rutina franquista, es un ejemplo especialmente rico de la hibridación con la cultura musical popular», como escribe Pardo, que añade:

Gil de Biedma y su homenaje a la chanson francesa; Ángel González, con sus múltiples poemas de tema musical, del tango a la habanera; Caballero Bonald y el flamenco; Francisco Brines con sus poemas dedicados al jazz. La política, para estos poetas, equivalía a una educación sentimental, y el deseo —el gusto- era más subversivo que un panfleto. En esta huida de la grandeza y abandono de la música «culta», sobresalen dos títulos: Blanco Spirituals, de Félix Grande, y Blues castellano, de Antonio Gamoneda (Pardo, 2013: 86).

En el caso de Ángel González, su gusto por la música fue muy temprano, como muestran las siguientes declaraciones, que es preciso citar pese a su extensión:

Desde niño sentí un enorme interés por la música. La primera vez que oí tocar un piano creo que estuve a punto 
de sufrir un desvanecimiento, sentí una sensación como de mareo, y tendría yo entonces tres o cuatro años. Por desgracia, en mi casa no había instrumentos musicales, nadie en mi familia se interesó por la música. La falta de instrumentos musicales en casa fue durante mi infancia una especie de catástrofe, que traté de remediar como pude. Logré hacerme primero con un xilófono, luego con una guitarra, y más tarde con un violín.

En solitario, estudié solfeo cuando mi enfermedad y, más tarde, tomé durante un año o dos clase de piano. Pero en mi casa no había piano, no podía practicar, y mis progresos eran mínimos. Así que lo dejé. También toqué algo un violín que me regalaron cuando tenía trece o catorce años. A la guitarra le dediqué más tiempo. Comencé a tocarla durante la guerra civil, mi primer maestro de guitarra fue un sargento de la Legión. Los legionarios estaban acuartelados cerca de casa, y el jefe de la banda de cornetas tocaba la guitarra en una taberna que había debajo de mi casa. Yo me pasaba el tiempo oyéndolo y observándolo, y un buen día me dejó la guitarra y me enseñó los rudimentos más elementales (González, 1990: 28).

En su juventud, por otro lado, Ángel González ejerció la crítica musical en la prensa asturiana a finales de la década del 40. Entre 1944 y 1947, enfermo de tuberculosis, había residido, por consejo médico, en el pueblo leonés de Páramo del Sil, y durante algunos meses del último año en otro pueblo del mismo término municipal, Primout, como maestro sustituto. En agosto regresó a Oviedo y ese mismo año comenzó su labor de crítico musical en La Voz de Asturias con el seudónimo de Bercelius, tomado del protagonista de El amante vagabundo, "la novela de William J. Locke que tanto había impresionado a Ángel en el despertar de su adolescencia» (García Montero, 2009: 401). Bercelius Nibbidart Paragot era un joven arquitecto que por un chantaje amoroso se había transformado en un vagabundo que deambulaba por Europa con su violín. En sus críticas musicales, Ángel González «se sentía más cómodo al firmar como Bercelius [...], simulador y brillante crítico musical de La Voz de Asturias, interesado de forma manifiesta por el violín, el piano, la guitarra española y el circo» (ibíd.: 402), como se sentiría más a gusto firmando con el nombre familiar de Cano sus «críticas urbanas de jacobinismo sigiloso» y con el seudónimo Belvedere sus crónicas futbolísticas (ibíd.: 402-403). No sabemos la influencia que la crítica musical pudo tener sobre su poesía, aunque no es dificil adivinar lo que supuso como acrecentamiento de sus 
conocimientos musicales y afinamiento del gusto y la sensibilidad artística. El periodismo no fue la profesión de Ángel González después y solo «a ratos» o a rachas lo practicó, como indica el título 50 años de periodismo a ratos y otras prosas (1998), con prólogo y selección de Susana Rivera, una muestra suficientemente amplia como para calibrar el trabajo periodístico del poeta asturiano entre 1947 y 1992.

En nuestro análisis no tratamos el campo resbaladizo de las posibles influencias musicales en la poesía de Ángel González, que parecen existir, al menos, en la configuración formal de algunos poemas. Alarcos Llorach alude al asunto en más de una ocasión al hablar de «una estructura y un desarrollo musicales de los contenidos» (Alarcos Llorach, 1969: 61), de «técnica musical» (ibíd.: 103) y de «desarrollo de tipo musical» (ibíd.: 61), refiriéndose con ello a algo «muy típico» de la poesía de Ángel González: «Un tema sobre el que se hacen variaciones» (ibíd.: 98) o "variaciones del tema central» (ibíd.: 107), aclarando que se trata de sustancias de contenido que «se desarrollan musicalmente, a través del tiempo»:

Se trata de bien combinar los contenidos con el tiempo (no de que la expresión fónica sea especialmente musical). Al hablar aquí de «música» no quiere decirse que Ángel González sea un poeta «sonoro», que sus poemas suenen al oído como cantinelas armónicas y pegadizas [...], sino de que sus poemas presentan una estructura y un desarrollo musicales de los contenidos (ibíd.: 61).

No está hablando Alarcos de otra cosa que del «ritmo de contenido» al que se somete la "expresión rítmica particular» o «ritmo métrico» (Alarcos Llorach, 1969: 62), que analiza en el poema «Domingo» de Sin esperanza, con convencimiento (1961). Una vez más, el «desarrollo musical» de un poema no pasa de ser una apreciación metafórica, pues el ritmo poético, suma —y no solo- del ritmo métrico y el ritmo de contenido, es algo propio de la poesía y no de la música, como el ritmo musical lo es únicamente de la música. Como hemos anunciado, nuestro análisis se circunscribe básicamente a dos aspectos: las alusiones, metáforas e intertextos musicales presentes en la poesía de Ángel González, que en ocasiones representan el traslado de la terminología musical a la poesía («tierno balido gregoriano»), y los poemas de tema musical o referencias musicales que contribuyen decisivamente a intensificar o determinar el desarrollo, la expresividad y el sentido del texto. 
La metáfora, musical o no, refuerza el poder de sugerencia de la expresión poética, aportando valores connotativos que se añaden o superponen a los contenidos lógicos del lenguaje, dotando a aquella de una rica polivalencia. «Alba en Cazorla» (González, 2001:61), por ejemplo, de Otoños y otras luces, dibuja un amanecer anunciado hiperbólicamente por el canto de «mil gallos»: «Luz tan cacareada / pocas veces se ha visto. / ¿Qué traerá este día anunciado / con clarines más vivos que sus llamas?». No es rara la mención de instrumentos musicales en la poesía de Ángel González, con cierta querencia por el violín; aquí los cantos de los gallos que anuncian el romper del día, como tantas otras veces en la tradición poética, del Mio Cid a García Lorca, se metaforizan como «clarines». El clarín se caracteriza por su sonido agudo, metáfora sinestésica, como lo es la adjetivación "clarines más vivos» aplicado comúnmente al fuego, a las llamas, y aquí también a los clarines o cantos de los gallos. La metáfora musical aporta plasticidad a la expresión y valores que enriquecen la lectura (los presentes en el poema - vivacidad, agudeza—, más otros posibles como alegría, claridad, etc.).

Hay que preguntarse ahora por el significado de las metáforas musicales en la poesía de Ángel González. Comienzan a aparecer en Sin esperanza, con convencimiento (1961), segundo libro de poesía del autor, que había publicado Áspero mundo en 1956. Alarcos Llorach se ha referido a lo que él llama sustancia del contenido, bastante explícita en el titulo de aquel poemario: el hombre actual, como sus antepasados, ha de dejar su legado de humanidad a los hombres del futuro:

No hay esperanza, no se cuenta con ella, pero se instaura el convencimiento de que cada uno de los hombres está aquí, en la vida, para algo útil: el constante renacer de la vida humana, su perfeccionamiento, no el propio (mío, tuyo o suyo), sino el de los hombres por venir (Alarcos Llorach, 1969:27).

Pero lo importante es cómo se informa esa temática. La crítica, en general, ha aludido a la técnica del contraste: «dos planos que se entrecruzan, se complementan o chocan» (Alarcos Llorach, 1969: 72), «un movimiento de opuestos» (Baena, 2007: 99), «dos secuencias tonales contrapuestas», la «irónica» y la «seria» (Romano, 2003: 103), etc. El poema «Otro tiempo vendrá distinto a este» $(65)^{1}$ apa-

1 Las citas se efectúan por Palabra sobre palabra (González, 2002), incluyendo solo la página correspondiente, excepto las provenientes de los libros posteriores, Otoños y otras luces (González, 2001) y Nada grave (González, 2008). 
rece organizado visual (blanco de línea que separa los dos planos o partes del poema) y gramaticalmente (partición por medio de la adversativa "pero») en los dos planos señalados, oponiendo un futuro ideal o soñado a la realidad dura del presente; lo positivo que después se niega se formula con el verso "violines estirándose indolentes», que en tal contexto presenta connotaciones semejantes a «bellas palabras calificativas», que, a su vez, nos hacen pensar en la oposición de dos concepciones de la poesía, evasiva («alguien dirá»), a la que el poeta opone su propio decir comprometido con el tiempo que vive. Con la misma técnica contrastiva, «El recuerdo» (78) aparece metaforizado como «canto» en lo que puede tener de atractivo señuelo adormecedor si el poeta no opusiera su lucidez y, como nuevo Ulises, cerrara los oídos al canto de sirena del recuerdo grato y apacible. El episodio odiseico lo evoca González, en un contexto crítico e irónico, en "Civilización de la opulencia» (225226), de Tratado de urbanismo.

Pero la música ofrece también otras connotaciones diferentes, sin ánimo de agotar el repertorio metafórico o la mera referencia. Puede significar compañía, solidaridad, ser símbolo identitario o de un mundo superior, o significar un determinado estado sentimental del sujeto (alegría, melancolía, etc.). Esta última función se percibe, por ejemplo, en la imagen «borrosa música» del poema «Las palabras inútiles» (189-190), de la colección de cinco poemas Palabra sobre palabra (1965), título que serviría después para la poesía completa de González. La breve colección de 1965 es un intenso canto de amor en el que, además, «late el asunto de la escritura y de la creación poética» (Debicki, 1989: 36). En efecto, «Las palabras inútiles» cifran la precariedad de la poesía, que no es capaz de «hacer», sino solo de «decir», pero con términos «huidizos» que no acaban de precisar con exactitud el sentimiento del sujeto, ensayando frases de sentido amoroso y, ante su ineficacia, otras acordes con el deseo del poeta de ver en los ojos de la amada "claras sombras» que hacia él avanzan; el oxímoron atrae otro ensayo de posibles frases sustitutivas y que insisten en la imprecisión del lenguaje, pero también en un ánimo sentimental impregnado de ansiedad y acaso de melancolía: «humo en la tarde, / borrosa música que llueve del otoño, / niebla que cae despacio sobre un valle».

En este breve recorrido por el universo imaginario del poeta Ángel González relacionado con la música, nos demoraremos sobre tres poemas en los que la imagen musical afecta en buena parte a su forma y desarrollo: «Elegía pura» (298), de Muestra, corregida y aumentada, de algunos procedimientos narrativos y de las actitudes sentimentales 
que habitualmente comportan $(1977)^{2}$, «Crepúsculo, Albuquerque, estío» (361), de Prosemas o menos (1985), y «Este cielo», de Otoños y otras luces (González, 2001: 19).

«Elegía pura» consta de nueve versos:

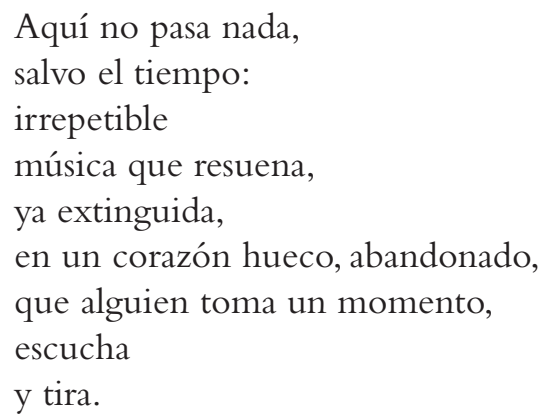

El poema incide sobre el tema central del libro en el que aparece, Muestra: el tiempo y sus efectos sobre el ser humano (Benson, 1978-1979: 44; Debicki, 1989: 72). La música —arte temporalsirve de imagen a la fugacidad del tiempo, irrepetible aunque permanezcan huellas o resonancias íntimas de lo ya acabado.

«Crepúsculo, Albuquerque, estío» forma parte de la sección segunda de Prosemas o menos, titulada "American landscapes», piezas tildadas de «instantáneas americanas» por unos (Díaz de Castro, 1990: 46) y de «viñetas» por otros (Debicki, 1989: 87), pues se trata de poemas sobre paisajes de Nuevo México donde vivió González algún tiempo. El poema es el primero de los cuatro "crepúsculos» en distintos momentos del año:

¡Sol sostenido en el poniente, alta

polifonía de la luz!

Desde el otro confin del horizonte, la montaña coral — madera y vientoresponde con un denso acorde cárdeno a la larga cadencia de la tarde.

La imagen visual del crepúsculo deriva hacia la metaforía musical que es todo el poema. De la sinestesia «polifonía de la luz» brota la visión crepuscular como una inmensa y armónica orquestación («montaña coral» formada por instrumentos o por voces

2 En adelante, Muestra. 
de madera - pinos, por ejemplo - y viento) que, por otra parte, relevan las ajustadas aliteraciones de los dos versos finales: «acorde cárdeno / a la larga cadencia de la tarde». "La metáfora de la música y el léxico a ella asociado permiten establecer en el texto [...] un juego de dobles sentidos, asociado ahora al placer melancólico de una contemplación extática» (Díaz de Castro, 1990: 47).

Con «Crepúsculo, Albuquerque, estío» puede relacionarse «Este cielo», de Otoños y otras luces, también de tema crepuscular:

El brillo del crepúsculo,

llamarada del día

que proclama que el día ha terminado

cuando aún es de día.

El acorde final que,

resonante,

dice el fin de la música

mientras la música se oye todavía.

Este cielo de otoño,

su imagen remansada en mis pupilas,

piadosa moratoria que la tarde concede

a la débil penumbra que aún me habita.

También aquí el crepúsculo se metaforiza como «acorde final» de la sinfonía de luz, resonante porque permanece como sonido (como imagen) cuando la música (el día) ya ha acabado. La imagen visual del crepúsculo se ha transformado imaginariamente en una imagen auditiva, espléndida sinestesia, como lo era el «acorde cárdeno» del poema anterior. En «Este cielo», la «imagen remansada» del crepúsculo acaba interiorizándose, haciendo del crepúsculo la metáfora de «la débil penumbra que aún me habita», en consonancia con la espacialización del paso del tiempo y el acento elegíaco en el que el poeta profundiza en Otoños y otras luces (Romano, 2003: 92-93).

No son los citados poemas de tema musical. La música ha servido únicamente de referencia o metáfora alusiva al tiempo fugaz o al estado de ánimo del sujeto.

En otros casos, determinadas citas o intertextos —abundantes en la obra de Ángel González- son de procedencia musical:

La música y la canción populares están muy presentes en su obra, como delatan los títulos de alguno de sus 
poemas («Tango de madrugada», «Vals del atardecer...»). En «Crepúsculo, Albuquerque, invierno» (pág. 363) ) $^{3}$ el verso que da sentido a todo el poema («la nieve ardía») está tomado de la siguiente jota: «Anoche soñé contigo / soñé que tú me querías / y por soñar que soñaba / soñé que la nieve ardía».Y el segundo verso de «Popular» (pág. 324), («oyó una voz en el aire»), única justificación del título, viene de esta canción asturiana: «Al pasar por tu ventana / oí una voz en el aire / quien quiera dormir conmigo / no tenga amores con nadie» (Rivera, 2006: 52).

Tras referirse al poema "Canción, glosa y cuestiones» (406), compuesto sobre un conocido vals latinoamericano ("Ese lunar, que tienes / cielito lindo...»), poema más o menos intrascendente que comentaremos más adelante, añade Rivera que «a veces, el acercamiento a la música ligera produce significaciones más serias», como ocurre en «La paloma» (244), donde la incorporación de unos versos de la habanera de igual título da lugar a un poema de contenido netamente político.

El interés interartístico es de mayor enjundia cuando el poema o los poemas abordan un tema musical o cuando las referencias musicales determinan en todo o en parte el desarrollo y el sentido del texto lírico. Basta con repasar el índice de los libros de González para sorprender títulos como «Vals del atardecer» (233), «Tango de madrugada» (234), «La trompeta» (235) y otros del «Intermedio de canciones, sonetos y otras músicas», de Tratado de urbanismo; "Quinteto enterramiento...", de Procedimientos narrativos; «Sonata para violín solo», «Reverbera la música en los muros», «Estoy bartok de todo», «Oda a la noche o letra para tango», de Muestra: estos y otros poemas certifican la impronta de la música en la poesía de Ángel González. Ya en su primer libro, Áspero mundo (1956), hay una sección de «Canciones», siete poemas en los que el término "canción» hay que relacionarlo no con la música, sino con las formas usadas por Juan Ramón Jiménez en su libro Canciones, por García Lorca en Libro de canciones o por Antonio Machado en Nuevas canciones, al igual que la «Canción triste de amigo» (438), de Deixis en fantasma, y la "Canción de amiga», de Otoños y otras luces, evocan las «cantigas de amigo» de los cancioneros gallego-portugueses, que en los castellanos poco a poco fueron siendo sustituidas por «canción», como ocurre en los poemas de González.

3 Modifico el número de página conforme a la edición de Palabra sobre palabra (2002) seguida a lo largo de este trabajo. 
En Grado elemental aparece el primer poema de Ángel González de largo desarrollo (139 vv.) condicionado por la música, «Penúltima nostalgia» (141-145). Dos tiempos contempla el poema: el presente desde el que, en un primer impulso nostálgico, se evocan momentos del pasado. Pero, como es habitual en la poesía de González, el poema se organiza sobre el contraste de una realidad parcial y, por tanto, engañosa o ilusoria - la que provoca, con dejos irónicos, la nostalgia de un aparente tiempo feliz - y la verdadera realidad:
Olvidamos, en cambio, los cadáveres, los campos de batalla, el hambre de los campos, las razones del hambre.

De ahí que el poeta apostrofe al tiempo ido para que le devuelva no solo la felicidad vivida de modo inconsciente, sino también los cadáveres y el sufrimiento, dejando junto al violín y la trompeta un revólver, una pistola: "También yo fui testigo de otras horas». La evocación nostálgica se remite a la música, a la moda de cada momento sucesivo:

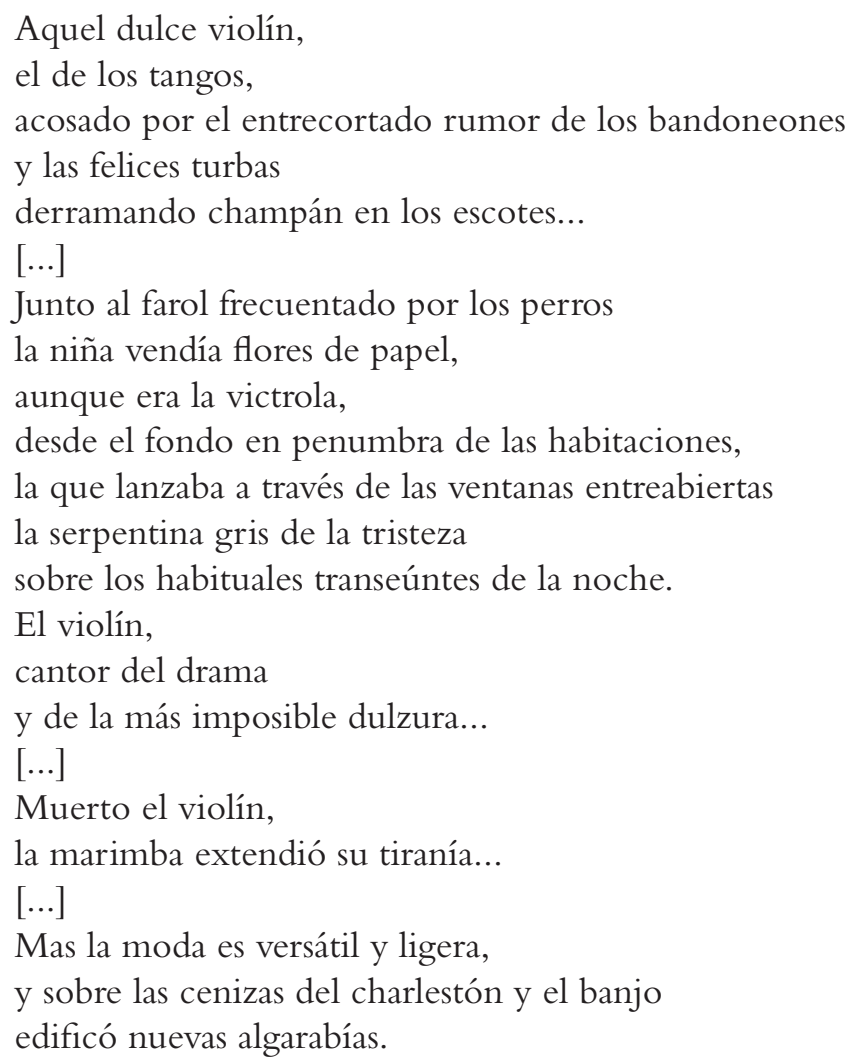


Y volvieron los blues, y las síncopas

llenaron de inquietud y carcajadas

el azaroso amanecer...

[...]

Las brillantes trompetas y el sinuoso

saxo

- y el torpe, exacto, articulado y grave

trombón de varas—- juntos

disonaron frenéticos...

El poema parece que nació "como consecuencia de la conocida y popular película El último cuplé. Esta era una melancólica e introvertida añoranza del tiempo pasado, de sus frívolos e intrascendentes entretenimientos», indica Alarcos Llorach (1969: 34), que fue el primero que realizó una extensa exégesis del desarrollo formal del poema, de su «insistencia enumerativa» (ibíd.: 116-124). Debicki, por su parte, sitúa la evocación de las modas musicales «a partir de principios del Siglo Veinte», observando notas de humor en la «melancólica añoranza» que salta después, por oposición, a la tragedia de la guerra civil (Debicki, 1989: 30-32). Los dos planos del poema ofrecen, para otro crítico, una «condición paradójica» que radica en «una correspondencia truncada entre un contenido social y otro histórico» (Baena, 2007: 362).

Los poemas de contenido musical van teniendo mayor presencia en los poemarios posteriores a Grado elemental. Tratado de urbanismo sitúa entre la primera sección, "Ciudad uno», y la última, "Ciudad cero", otra intermedia titulada "Intermedio de canciones, sonetos y otras músicas» (231-245), diez poemas de los que la mitad son de temática musical en mayor o menor grado: «Vals del atardecer», «Tango de madrugada», «La trompeta (Louis Armstrong)», «Canción para cantar una canción» y «La paloma (Versión libre)». La sección «combina poesía y música, en combinaciones muy marcadas rítmicamente que abordan, melódica y temáticamente, distintos géneros musicales: vals, tango, jazz, canción popular, asociados por la angustia temporal, el amor, la historia política» (Romano, 2003: 104). Los poemas evocan diferentes géneros musicales, aprovechan algunas letras de canciones y aun es posible que el ritmo poético quiera acomodarse al ritmo musical o incluso que haya un planteamiento musical del poema; pero siempre y solo será poesía; de ahí que nos parezca mejor decir que se trata de «evocaciones subjetivas y nostálgicas de amor y de formas musicales del pasado» (Debicki, 1989: 41). 
$\mathrm{El}$ «Vals del atardecer», por ejemplo, con su concurrencia instrumental de violines y violas, trompetas, flautas, arpas, oboes y violoncelos, no solo sugiere el ritmo de baile y música del género, sino que expande cierto aire desenvuelto y festivo que se muestra incluso en el juego con el título del conocido vals de Strauss: «El vals de las solas»; de igual manera, bandoneón, guitarra y violín dan los distintos tonos del tango, su desgarro y los sensuales movimientos del baile, añadiendo una letra sugerente de tango, "(Sé que no has de volver)", que lo emparenta, por su aprovechamiento intertextual, con «La paloma» en «Versión libre», puesto que la fórmula de la canción «....adonde vivo yo» pasa a ser en el poema «...en donde vivo yo»; versión libre también porque el símbolo universal de la paloma es el que recorre el poema, de la posible esperanza inicial — paz, libertad en distintos pueblos y continentes- a su herida final y a su resistencia a cualquier signo (o régimen) que la quiera doblegar. Como interpreta una estudiosa, su carácter «lúdico y coloquial» utiliza «el prosaísmo y el montaje interdiscursivo" (el discurso del poeta y el de la popular canción hispanoamericana) "para hablar de la guerra en un sentido más universalizado, confrontada con una esperanza "paloma" que, pese a su resistencia, acaba muerta», señalando el «trasfondo irónico» del poema, «donde juegan polifónicamente la levedad de la canción y la seriedad del asunto» (Romano, 2003: 97). Para el autor es «el poema más caracterizadamente político (me parece) entre los que yo escribí hasta entonces» (González, 1980: 21).

Vals, tango, jazz y canción. Homenaje y sentimiento musical que se eleva en «Canción para cantar una canción» (237), poema en el que lo emocional ante el hecho musical cobra más cuerpo. La canción hace brotar el sentimiento de otro tiempo ya perdido, algo indefinible entre la emoción y la nostalgia, cuyo fruto final es la tristeza:

Esa música...
Insiste, hace daño
en el alma.
Viene tal vez de un tiempo
remoto, de una época imposible
perdida para siempre.
Sobrepasa los límites
de la música. Tiene materia,
aroma, es como polvo de algo
indefinible, de un recuerdo
que nunca se ha vivido,
de una vaga esperanza irrealizable. 
Se llama simplemente:

canción.

Pero no es solo eso.

Es también la tristeza.

El poema lo comentó en su día Alarcos Llorach:

El poeta - el hombre - sumergido en la vorágine del leteo nocturno y atemporal se ve sorprendido de pronto por «esa música» [...] asociada a vivencias remotas [...]. No es solo música, es algo que no solo se oye: se ve, se huele, se masca, se toca [...]: «se llama simplemente: canción». Mas el sentimiento nostálgico persiste y ha de reconocerse que «no es solo eso»: «es también la tristeza», la marejada incontenible del tiempo ido (Alarcos Llorach, 1969: 49).

Situado el «Intermedio...» entre la «Ciudad uno» — «visión crítica e irónica de la ciudad moderna» (Debicki, 1987: 127) — y la «Ciudad cero» — «una serie de evocaciones nostálgicas» (ibíd.)— debe ser entendido acaso como un "remanso estático» que busca soslayar la "desesperante soledad", remanso que en este caso consiste en entregarse a ámbitos en los que «bulle la espontaneidad ingenua de la canción popular y hasta popularizada: canciones y ritmos del pueblo, canciones y ritmos que desde otros pueblos se han generalizado», como es el caso del jazz en «La trompeta» (Alarcos Llorach, 1969: 46-48). El propio Ángel González se ha referido al «Intermedio de sonetos, canciones y otras músicas» como una ampliación imaginativa dentro de lo que era su poesía hasta este momento y contempla algunas novedades que caracterizarán, a su parecer, la segunda etapa de su poesía, tras cerrar la primera con Tratado de urbanismo:

Inicio cierta apertura hacia lo imaginativo, un acercamiento a temas intrascendentes (la música ligera) y una búsqueda, más a través del tono y de la estructura profunda del poema que de su organización estrófica, de una expresión próxima a la canción - aunque una de esas tentativas haya cuajado de una manera para mí inesperada en el poema más caracterizadamente político (me parece) entre los que yo escribí hasta entonces: «La paloma» (González, 1980: 21).

A medida que la obra del poeta avanza es inevitable que el lector vaya relacionando poemas nuevos con poemas anteriores por el 
título, por el tema o el asunto. Así sucede con el «Tango de madrugada» (234), de Tratado de urbanismo, y «Oda a la noche o letra para tango» (333), de Muestra, con ser poemas muy distintos:

«Tango de madrugada» explota el sentimentalismo epidérmico y desgarrado del tango, la emotividad floreciente y tumultuosa e, igualmente, su «Oda a la noche o letra para tango» parodia inicialmente el tono quejumbroso del tango para acabar en un festivo elogio de la nocturnidad (Payeras Grau, 1990: 41).

Otro estudioso vincula la «Oda a la noche o letra para tango» a la tendencia del poeta a expresar poéticamente, por medio de la ironía, la «degradación prosaica» de la época, que en el caso de González se vuelca sobre el propio ser, también sometido a «denigración autocrítica» (Sobejano, 2003:362-363). Sharon Keefe Ugalde, que propone el claroscuro como una clave para la lectura de la poesía de Ángel González, observa en la oda una «lúdica inversión [...] que transforma la negra noche, normalmente elemento de la constelación oscuridad-pesimismo, en algo brillante que alegra la existencia del poeta-hablante» (Ugalde, 2006: 81).

De igual modo, el recurso intertextual analizado en «Tango de madrugada» y en "La paloma» es el principio constructor de "Canción, glosa y cuestiones» (406), de Prosemas o menos, poemilla basado en la paronomasia entre «lunar» y «lugar» que transforma la suave sensualidad de la conocida canción del folclore mexicano en cruda sexualidad, a la vez que juega con la anfibología de «lugar común", que se refiere al sexo femenino sin dejar de sugerir la definición tradicional del «tópico» o «lugar común», perfectamente definido por el verso: "por lo citado y por lo concurrido". El poema, impregnado de parodia y humor, avanza, según indica el título, de la «canción» a la "glosa» y al planteamiento de "cuestiones» interrogativas. Debicki ha comentado el poema con cierto detalle:

Importa notar que este poema es extremadamente «culto» y cuidadosamente construido. Emplea varios niveles de lenguaje: empieza con ecos de una canción popular mexicana (muy romántica), que se socavan por medio de la alusión explícita al sexo femenino. Luego extiende su comentario por medio de la imagen del solar «superpoblado»; aunque el tono parece serio, la imagen produce desde luego un efecto absolutamente cómico. El verso final, con sus vocablos burocráticos, amplía la ironía de la obra, haciéndonos sentir que toda la realidad a la que se alude (la mujer, su sociedad, 
el lenguaje de su mundo y del hablante mismo) forma un mundo pedestre, ridículo y cursi. En su totalidad, el poema revela una gran maestría en el empleo de la alusión y del lenguaje para crear una gran sátira (Debicki, 1989: 99).

Los poemas de tema musical de Muestra se desarrollan en un ámbito existencial, a la vez que el sujeto aparece imbuido por la música. Me refiero a "Sonata para violín solo» (293), «Reverbera la música en los muros...» (295) y «Estoy bartok de todo...» (308). El primero lleva por subtítulo «(Juan Sebastián Bach)», por lo que hay que entender que brota de la audición de la sonata, que causa profunda conmoción en el poeta («la trayectoria cruel de este cuchillo / me está marcando el alma»), conmoción que no impide el marchamo reflexivo del poema y la constatación final de la desilusión, de la desesperanza: «El confuso perfil de un sueño roto, / el símbolo roído de una yerta esperanza».

«Estoy bartok de todo...» no deja de ser, pese a todo, un homenaje al famoso compositor húngaro del pasado siglo y a la propia música: violines, violas, fagot, oboe... se concitan en el homenaje; todo resuena en la cabeza del sujeto hasta el hartazgo, que sugiere el primer verso: «Estoy bartok de todo».Acaso la música propicie el ensimismamiento o un sentimiento tan gozoso que lleve a olvidarse de la realidad: «Puede ser peligrosa. / Échenla fuera». Aun así, el poema, en su juego con el nombre del compositor («Resuena bela en todo bartok...»), puede incluirse entre las «estrategias de desautomatización» que en este poema sugieren «la irónica prevención ante la música» (Romano, 2003: 122).

No menos turbador que la «Sonata para violín solo» es el poema «Reverbera la música en los muros...»:

Concluye igualmente aludiendo a esa capacidad de la música de crear un paraíso artificial, en este caso aplicado irónicamente a la sencilla sensación de existencia del yo: «Música que rechazan las paredes. / Solo soy eso. / Cuando ella cesa, también yo me extingo» (Díaz de Castro, 1990: 48).

El crítico relaciona el poema con «Revelación» (369), de Prosemas o menos, que comienza: «Dios existe en la música...»: «Toda la belleza, la armonía y la elevación espiritual que sugiere y puede provocar la música recoge aquellos atributos de lo divino que [...] podrían aceptarse como positivos e idílicos» (ibíd.). Pero el final del poema «Revelación» («iDios existe / en la música! / (Cuatro compases más y otra vez solos)») ofrece un «sentido dramático» que 
en los tres versos del poema siguiente, «Epílogo» (370), se resuelve en "tono de humor negro»: "Cuando el músico guarda el violoncelo / en su negro sarcófago, / el cadáver de Dios huele a resina». Como concluye un estudioso: «Con la música a otra parte... No hay armonía sideral ni humana, solamente hay un poco de tiempo que se nos va de entre las manos» (Mainer, 193: 18). La imagen del «negro sarcófago» del «Epílogo» no era nueva: había aparecido ya como "piano negro, / féretro entreabierto» en "Quinteto enterramiento para cuerda en cementerio rural» (275), de Procedimientos narrativos, un poema de asunto enteramente musical, con dos violines, una viola, un cello y un piano (un quinteto) que el autor va desgranando en símiles curiosos (violín-ruiseñor, viola-mariposa, segundo violín-lagarto) hasta llegar al piano y su fúnebre imagen literaria y visual. Sorprendida la imagen («féretro entreabierto»), el poeta la desarrolla con aire jovial. Los arcos sobre los instrumentos de cuerda trazan una cruz, el "pianista enlutado» semeja un familiar cercano del presunto difunto, por lo que, conforme a la frase convencional, «todos / te acompañamos en el sentimiento». El poema ofrece una cuidada organización, con tres paraestrofas dedicadas a los tres primeros instrumentos y otras tres centradas en el piano y pianista luctuosos. El mencionado aire jovial del poema, sin los alcances existenciales de otros anteriormente indicados, se muestra en recursos como los símiles sorprendentes o la homonimia del verso quinto: «la viola apenas viola / el reposo del aire». He aquí el «Quinteto...»:

El primer violín canta

en lo alto del llano

igual que un ruiseñor sobre un ciprés.

Como una mariposa,

la viola apenas viola

el reposo del aire.

Cruza el otro violín a ras del cello, semejante a un lagarto

que entre dos manchas verdes

deja solo el recuerdo de la luz de su cola.

Piano negro,

féretro entreabierto:

¿quién muere ahí? 
Sobre los instrumentos,

los arcos

dibujan lentamente

la señal de la cruz

casi en silencio.

Pianista enlutado

que demoras los dedos

en una frase grave, lenta, honda:

todos

te acompañamos en el sentimiento.

La música aparece en el poema libre de connotaciones elegíacas y semeja un cuadro de enterramiento «rural» como acusa el título. Lo visual de las imágenes (ruiseñor, ciprés, mariposa, lagarto, manchas verdes, piano negro, féretro entreabierto, pianista enlutado) prevalece incluso sobre el aspecto musical de los instrumentos. La plasticidad del poema es excelente puerta de entrada para el otro arte con el que se interrelaciona la poesía de Ángel González: la pintura.

\section{PINTURA Y POESÍA}

He sido bastante aficionado a la pintura, incluso dibujé algo. Anda por ahí algún libro con ilustraciones mías. Entre los pintores relativamente modernos hay uno que me desasosiega, hasta el punto de que cuando tengo cerca un cuadro suyo me parece que lo oigo, que me llama con una especie de susurro: Cézanne. Me parece muy superior a todo lo que vino después. Y antes de Cézanne, naturalmente, la pintura española de Goya y Velázquez (González, 1990: 29).

Sin embargo, no hay ningún poema relacionado con el pintor impresionista francés, ni con Goya; sí con Velázquez. En cualquier caso, si la música inspira o determina la temática y el desarrollo de una serie de poemas, además de servir para cuajar numerosas imágenes poéticas, son pocos los poemas sobre pintores o sobre cuadros, al igual que no abundan metáforas pictóricas como esta: «la mañana: / escorzo de cristal que pasa huyendo...» (402). Si nos fiamos del título, solo dos poemas son de carácter ecfrástico, «Palabras desprendidas de pinturas de José Hernández» (288), de Procedimientos narrativos, y «El Cristo de Velázquez», de Prosemas o 
menos, si bien, y según el parecer de Mary Makris (1993: 170), debieran añadirse: «Danae» (42), de Áspero mundo, «al parecer inspirado en la Danae de Tiziano", poema que Marcela Romano (2003: 116) analiza, sin referirse para nada a su correlato pictórico, como temprana muestra de algo más frecuente en la poesía posterior de González, «la parodia de formas cultas, personajes, historias, consagrados por el canon literario»; «El campo de batalla» (72), de Sin esperanza, con convencimiento, cuyo origen - indica Makris- es el Guernica de Picasso; y "Yarg Nairod», de Muestra, cuyo título resulta de la inversión de Dorian Gray, y que Makris entiende como «a reversal of the relationship of art to life found in Oscar Wilde's The Picture of Dorian Gray".

Superando el sentido retórico clásico de la écfrasis como descripción del objeto ausente, entendemos por tal, en la actualidad, «la transformación de un arte visual en otra forma verbal, causando así una confrontación única entre el tiempo y el espacio, entre la palabra y la visión, dentro de una sola experiencia sensorial» (Persin, 1991: 45). He aquí la diferencia básica, teorizada ya por Lessing, entre pintura y poesía, artes espacial y temporal respectivamente, frente al carácter temporal coincidente de música y poesía.

No es el momento de referirse a la larga historia de relaciones, a todos los niveles (teórico y creativo), entre pintura y poesía, ni siquiera de mencionar aquellos textos poéticos más citados en tanto que derivados de la pintura (Manuel Machado, Alberti, etc.) y que preceden a los de Ángel González en el siglo XX. Por razones comprensibles nos limitamos a lanzar una mirada sobre los dos poemas claramente ecfrásticos de González, «Palabras desprendidas de pinturas de José Hernández» y «El Cristo de Velázquez», si bien nos detendremos únicamente en el segundo. Los dos poemas cuentan con sendos excelentes análisis de Mary Makris (1991 y 1993).

En la lectura de un texto determinado, el título, si existe, es lo primero con que nos encontramos. El título es la primera señal pragmática de entendimiento del texto. En el caso de los poemas señalados de González puede añadirse que el título les confiere, de inicio, un carácter ecfrástico, en el sentido extenso de "écfrasis» que se ha enunciado. Es el valor añadido a la calidad informativa del título en cuanto tal: informa sobre el poema y, a la vez, en el caso de «El Cristo de Velázquez», sobre un cuadro e incluso, en el ámbito de saberes de un lector habituado a la poesía, sobre un 
poema anterior, El Cristo de Velázquez (1920) de Unamuno. El título del poema de Ángel González repite los dos anteriores y, por lo tanto, remite a ellos. A la función catafórica de cualquier título se suma aquí una referencia anafórica, en este caso de doble intertextualidad, pictórica y poética. En otras ocasiones he llamado «jánicos» a estos títulos que miran hacia textos previos y, a la vez, hacia el propio poema que encabezan. El carácter anafórico del título del poema implica, además, que aquello que se repite verbalmente («El Cristo de Velázquez») es un objeto ausente, aludido únicamente. De ahí la tendencia a la écfrasis, en los poemas sobre cuadros, a la descripción, con el fin de hacerlos presentes en la memoria o en la imaginación del lector. Por otro lado, el propio título alude ya a la «mímesis doble» (Riffaterre, 2000: 162), en cuanto que el poema es representación de representaciones previas.

Aunque el carácter del título de «Palabras desprendidas de pinturas de José Hernández» es distinto, pues no remite a otro título ni a un cuadro concreto, coincide con «El Cristo de Velázquez» en el «efecto de elogio» (Riffaterre, 2000: 166) que resulta de un poema ecfrástico. Aun así se trata de poemas muy diferentes de formato y sentido. El primero es aparentemente más complejo, entre otras razones porque no se refiere a un cuadro determinado, sino a las obras ("pinturas») de un pintor que le han sugerido o inspirado al poeta una serie de palabras que no son arbitrarias, sino «desprendidas» de la contemplación de aquellas pinturas. Sabemos de qué pinturas se trata. En 1971, un año antes de que el poema de González se publicara en Procedimientos narrativos, apareció la serie Ópera del pintor José Hernández, compuesta de seis litografias con los dos poemas de Ángel que componen «Palabras desprendidas»: «Alborada» $\mathrm{y}$ «Fin del último acto». Por su parte, Makris escribe:

The reader may find reproductions of the Opera series that inspired González in Ángel González García’s anthology José Hernández (Madrid: Ediciones Turner, 1978). Hernández actually as two series of lithographs entitled Opera. The titles of the three prints that make up the second series are: «Opera, primer acto», «Opera, segundo acto» and «Opera, último acto». Because of the similarity of titles, González's poem «Fin del último acto» is probably also indebted to the last of this second series of lithographs (Makris, 1993: 170).

La propia Mary Makris, como ya se ha indicado, realizó un preciso y precioso análisis del poema y a él remito, para centrarme en las líneas que siguen en «El Cristo de Velázquez», incluido 
dentro de la serie "Teoelegía y moral», «la que más descarnadamente parodia el discurso evangélico desde una perspectiva absolutamente escéptica» (Romano, 2003:119). El poema está dedicado a Luis Ríus (1930-1984), de la segunda generación del exilio español en México:

Banderillero desganado.

Las guedejas del sueño cubren tu ojo derecho.

Te quedaste dormido con los brazos alzados, y un derrote de Dios te ha atravesado el pecho.

Un piadoso pincel lavó con leves algodones de luz tu carne herida, y otra vez la apariencia de la vida a florecer sobre tu piel se atreve.

No burlaste a la muerte. No pudiste. El cuerno y el pincel, confabulados, dejaron tu derrota confirmada.

Fue una aventura absurda, bella y triste, que aún estremece a los aficionados: ¡qué cornada, Dios mío, qué cornada!

Es también Mary Makris (1991) la que ha efectuado el análisis más minucioso y extenso del poema, examinando sus relaciones intertextuales (con el cuadro de Velázquez, el texto unamuniano, discursos implícitos de la tauromaquia y la religión), que dotan al poema de polivalencia semiótica y de dimensión metapoética, además de presentarse como un collage verbal en el que convergen múltiples niveles de significación, collage al que puede sumarse, según Marcela Romano (2003: 128), la voz trágica de Miguel Hernández en el correlato muerte-toro que establece González en su poema. Romano habla de la «reducción valorativa» del poema: banderillero en vez de torero, aficionados por creyentes, interpretando el «Dios mío» del verso final como «un vocativo, que confirma la ironía enunciativa merced a la analogía establecida entre el Dios Padre y el cruel torero que ha dado muerte al propio Hijo Unigénito» (ibíd.: 112).

Para Debicki el efecto del poema depende de la contraposición entre lo convencional (muerte de Cristo, Velázquez, «tal vez el famoso poema de Unamuno») y la sorprendente imagen de Cristobanderillero; pero «la aparente irreverencia, sin embargo, apunta 
a una visión compasiva (e irónica) de la tragedia de un idealista» (Debicki, 1989: 93), efecto ya anticipado por Rovira (1985:10). La idea la matiza García de la Concha:

A mi juicio conviene tener presente que en ese cuadro vio Unamuno el evangelio nacional de España; y en ese marco, como contrafactura irónica de las alegorías que don Miguel fue adivinando en la pintura, debe leerse el poema. Por lo que hace al segundo es claro que en él se parodia el idealismo con que los creyentes presentan el misterio, a la vez que se denuncia un concepto egoísta de la religión (García de la Concha, 1996: 51).

En cuanto a la traducción verbal de un texto pictórico, determinados elementos descriptivos evidencian la pintura velazqueña: las guedejas que cubren el ojo derecho del Crucificado (v. 2), «los brazos alzados» (v. 3), la llaga del pecho (cornada); se alude al pincel (vv. 5 y 10)... La forma métrica del poema (soneto irregular, rimas incompletas) se corresponde con «el tono a medias entre la unción y la broma» (Mainer, 1993: 18), y la materia sonora del poema se acompasa perfectamente con el tono y el sentido en cada caso, como se comprueba en la segunda estrofa, la más "compasiva» del soneto, la de mayor suavidad sonora: «Un piadoso pincel lavó con leves / algodones...».

La traducción verbal de una imagen supone un doble viaje: de la imagen al texto para el autor y del texto a la imagen para el lector. En este sentido, siempre se ha planteado la cuestión de la autonomía de un texto verbal o poético cuyo origen es otro texto, pictórico en este caso. Parece claro que el poema de González sobre el Cristo de Velázquez no hubiera existido sin la previa existencia del Cristo velazqueño, de la misma manera que el Quijote no se hubiera escrito, o sería muy otro, sin la existencia de los libros de caballería. El funcionamiento autónomo del texto ecfrástico no supone, sin embargo, independencia total del texto pictórico anterior:

La descripción ekfrástica de una imagen, aunque pueda funcionar con total autonomía, como texto, siempre arrastra esa silenciosa conciencia de saberse vicaria, conocedora de su íntima y secreta heteronomía, porque las palabras - como un eco- activan la potencial resonancia de las imágenes vividas (De la Calle, 2005: 17).

El texto ecfrástico ofrece lo que De la Calle llama un «objeto estético», es decir, la "personal experiencia estética» del poeta en su 
«diálogo permanente ante/con la obra» de arte (De la Calle, 2005: 18). Indudablemente, la écfrasis parte de una experiencia contemplativa, real o imaginaria - puesto que hay textos sobre cuadros supuestos, inexistentes-, y desemboca en una «interpretación», poética en nuestro caso. El camino del autor y el del lector son de sentido contrario: de la fruición contemplativa a la escritura y de la fruición poética a la contemplación real, imaginaria o recordada. El texto poético, autónomo como obra de arte, ejerce a la vez, y por lo dicho, una función mediadora que no cabe minusvalorar. Más aún, ejerce algo que no se suele señalar: una función de síntesis o confluencia estética, ideológica, de experiencias artísticas y vitales, de interacciones creativas y lectoras, etc. El texto ecfrástico es, en efecto, un «objeto estético», más allá del «objeto artístico» que es el poema, síntesis de procesos diferentes (autor, lector) y de diferentes resultados. 


\section{BIBLIOGRAFÍA}

Alarcos Llorach, Emilio (1969). Ángel González, poeta

(Variaciones críticas), Oviedo, Universidad de Oviedo.

BAEnA, Enrique (2007). Metáforas del compromiso (Configuraciones de la poética actual y creación de Ángel González), Madrid, Cátedra.

Benson, Douglas (1978-1979). «Ángel González y Muestra: Las perspectivas de una sensibilidad irónica», Revista Hispánica Moderna, 40, 1-2, pp. 42-59.

Deвiскі, Andrew P. (1987). «Ángel González: transformación y perspectivas», en Poesía del conocimiento. La generación española de 1956-1971, Madrid-Gijón, Júcar, pp. 109-138.

- (1989). Ángel González, Madrid-Gijón, Júcar.

De la Calle, Román (2005). El espejo de la écfrasis. Más acá de la imagen:

Más allá del texto, Madrid, Fundación César Manrique.

Díaz de Castro, Francisco (1990). «Lectura de Prosemas o menos», Anthropos, 109, pp. 44-51.

GAMONEDA, Antonio (1997). «Sobre Nazim Hikmet, los negro spirituals y mi Blues castellano", en El cuerpo de los símbolos, Madrid, Huerga y Fierro, pp. 81-98.

García de la Concha,Víctor (1996). «Tiempo e historia en la autobiografia de Ángel González», en Ángel González, Luz, o fuego, o vida, Salamanca, Universidad de Salamanca / Patrimonio Nacional, pp. 7-57.

García Montero, Luis (2009). Mañana no será lo que Dios quiera, Madrid,Alfaguara.

GonZÁlez, Ángel (1980). «Introducción», en Poemas, ed.

Ángel González, Madrid, Cátedra, pp. 11-24.

- (1990). «Autopercepción intelectual de un proceso histórico. Para

que yo me llame Ángel González», Anthropos, 109, pp. 19-29.

- (1998). 50 años de periodismo a ratos y otras prosas, Oviedo, Nobel.

- (2001). Otoños y otras luces, Barcelona, Tusquets.

- (2002). Palabra sobre palabra, Barcelona, Seix Barral.

— (2008). Nada grave, Madrid,Visor.

Mainer, José-Carlos (1993). «De una teología y una coincidencia», Poesía en el Campus, 24, pp. 17-19. 
Makris, Mary (1991). «Intertextualidad, discurso y ékfrasis en "El Cristo de Velázquez” de Ángel González», en En homenaje a Ángel González: Ensayos, entrevistas y poemas, eds. Andrew P. Debicki y Sharon Keefe Ugalde, Boulder, Colorado, Society of Spanish and Spanish-American Studies, pp. 73-83.

- (1993). «Collage as metapoetry in Ángel González's "Palabras desprendidas de pinturas de José Hernández" ", Anales de la Literatura Española Contemporánea, 18, 1-3, pp. 157-172.

PANTINI, Emilia (2002). «La literatura y las demás artes», en Introducción a la literatura comparada, ed. Armando Gnisci, Barcelona, Crítica, pp. 215-240.

PARdo, Carlos (2013). «Wagner en Carrefour: efectos secundarios del simbolismo musical», en Malos tiempos para la épica. Última poesía española (2001-2012), eds. Luis Bagué Quílez y Alberto Santamaría, Madrid,Visor, pp. 79-92.

Payeras Grau, María (1990). «Ángel González: un espíritu burlón», Anthropos, 109, pp. 35-44.

Persin, Margaret (1991). «La imagen del/en el texto: el ékfrasis, lo post-moderno y la poesía española del siglo XX», en Novísimos, postnovísimos, clásicos: la poesía de los años 80 en España, ed. Biruté Ciplijauskaité, Madrid, Orígenes, pp. 43-63.

Riffaterre, Michael (2003). «La ilusión de écfrasis», en Literatura y pintura, comp. Antonio Monegal, Madrid, Arco Libros, pp. 161-183 (título original, «L'illusion d'ekfrasis», 1994).

Rivera, Susan D. (2006). «Intertextualidad y collage», en Ángel González, un clásico de nuestro tiempo, coords. José Guerrero y otros, Almería, Universidad de Almería, pp. 41-57.

Romano, Marcela (2003). Almas en borrador. Sobre la poesía de Ángel González y Jaime Gil de Biedma, Mar del Plata, Martín.

Rovira, Pere (1985). «Los prosemas de Ángel González», Ínsula, 469, pp. 1 y 10.

Sobejano, Gonzalo (2003). «Salvación de la prosa, belleza de la necesidad en la poesía de Ángel González», en Inminencia y trascendencia en poesía (De Lope de Vega a Claudio Rodríguez), Salamanca, Almar, pp. 353-377.

UGAlde, Sharon Keefe (2006). «El claroscuro», en Ángel González, un clásico de nuestro tiempo, coords. José Guerrero y otros, Almería, Universidad de Almería, pp. 69-85.

Urrutia, Jorge (2013). Hallar la búsqueda (La construcción del Simbolismo español), Valladolid-New York, Junta de Castilla y León/Universidad de Valladolid. 